\title{
Implikasi Pencegahan Dumping Sebagai Unfair Trade Practices Terhadap Negara Berkembang
}

\author{
Eunike Trisnawati*; Mochammad Farisi; Doni Yusra \\ Pebrianto \\ Fakultas Hukum Universitas Jambi \\ *Coresponding author: euniketrisnawati@unja.ac.id \\ Submission : 14 Juli 2020 \\ Revision : 31 Oktober 2020 \\ Publication : 23 November 2020
}

\begin{abstract}
Dumping is a trade activity by the exporter do by selling commodity in international markets at a price less than normal value or under than commodity price in the importer countries. until this cause problem as unfair trade practices. Some dumping prevention polices born to protect domestic market from unfair trade practices. However that polices often misused, not uncommon developed countries doing the protection for their domestic industry. In trade who abused can trigger unfair trade practices. This type of research is normative juridical. This study discusses and analyze how impact of application Article VI of Agreement on tariff and trade in preventing dumping dictionary, dumping in value as unfair trade practices, but in reality Anti-dumping and protectionism practice towards developing countries shows that application of anti-dumping duties and protectionism need to be given special attention and must match with procedures contained in Antidumping code. This has purpose to reduce protection measures which can be harmful to other countries who do export activities especially developing countries. World organization need towatch over trade activities against all forms resistance who created unfair trade practices by considering policies which already existed.
\end{abstract}

Keyword: Developing Country; Dumping Prevention; Unfair Trade Practices 


\begin{abstract}
Abstrak
Dumping adalah kegiatan dagang yang dilakukan eksportir dengan menjual komoditi di pasar internasional dengan harga kurang dari nilai wajar atau lebih rendah dari harga barang tersebut di negara importir. Hal ini menyebabkan persaingan menjadi tidak sehat. Beberapa kebijakan pencegahan dumping lahir sebagai upaya untuk mengurangi kecurangan yang terjadi dalam praktek perdagangan. Namun kebijakan-kebijakan tersebut sering disalahgunakan, tidak jarang negara-negara maju melakukan proteksi untuk melindungi industri dalam negerinya. Dalam kamus perdagangan, dumping dinilai sebagai bentuk dari persaingan yang tidak sehat, namun nyatanya, Anti-dumping dan proteksionisme yang disalahgunakan dapat memicu terjadinya Unfair Trade Practices. jenis penelitian ini adalah yuridis normatif, Penelitian ini membahas dan menganalisis bagaimana dampak penerapan Pasal VI General Agreement on Tariff and Trade dalam mencegah praktik dumping terhadap negara berkembang bahwa penerapan kebijakan Anti-dumping dan proteksionisme perlu diperhatikan lebih khusus dan harus sesuai dengan prosedur yang terdapat dalam Anti-dumping Code hal ini bertujuan untuk mengurangi tindakan-tindakan proteksi yang dapat merugikan negara-negara yang melakukan ekspor terutama negara berkembang, perlunya peran WTO dalam mengawasi kegiatan perdagangan terhadap segala bentuk hambatan yang dapat menciptakan perdagangan yang tidak adil, dengan mempertimbangkan kebijakan-kebijakan yang telah ada.
\end{abstract}

\title{
Kata Kunci: Negara Berkembang; Pencegahan Dumping; Unfair Trade Practices
}

\section{A. Pendahuluan}

Dalam era globalisasi yang semakin maju, perkembangan bisnis dan ekonomi internasional antar negara menjadi hal yang sangat penting, bebas dan terbuka. Proses dari globalisasi tersebut secara langsung dapat meningkatkan hubungan kerja sama dalam kegiatan ekspor dan impor bahkan mempersatukan kegiatan ekonomi diseluruh dunia tanpa adanya batas-batas tertentu (free trade). Perdagangan internasional dilakukan karena adanya kesadaran akan 
pentingnya kerja sama antar lintas batas negara, sehingga hal tersebut menyebabkan ketergantungan antar negara menjadi meningkat. ${ }^{1}$ Dalam ekonomi internasional terdapat beberapa teori yang dipelajari yakni: Teori Murni Perdagangan (The Pure Theory of Trade) teori ini membahas dasar terjadinya perdagangan internasional, Teori Kebijakan Perdagangan (The Theory of Commercial Policy) teori yang membahas mengenai alasan timbulnya perdagangan bebas, proteksionisme dan hambatan-hambatan dalam perdagangan internasional. ${ }^{2}$

Ciri khas perdagangan internasional ditandai dengan adanya hubungan dagang yang mengikuti suatu sistem dan spesifikasi yang mengarah pada kegiatan demi mewujudkan tujuan tertentu yang diinginkan dalam perdagangan. ${ }^{3}$ Keinginan akan terbentuknya organisasi yang bersifat multilateral diharapkan dapat mengatur dan mengawasi masalah perdagangan global yang melibatkan negara-negara didunia demi terwujudnya perdagangan yang dicita-citakan, dengan membentuk organisasi dunia seperti International Trade Law (ITO), General Agreement on Tariff and Trade (GATT) 1947 dan World Trade Organization (WTO). ${ }^{4}$ World Trade Organization merupakan satu-satunya badan internasional yang secara khusus mengatur tentang masalah

1 WahonoDiphayana. Perdagangan Internasional. DEEPPUBLISH. Ngaglik. Sleman. 2018. hal. 1.

2 Ibid. hal. 2

${ }^{3}$ Christhophorus Barutu. Sejarah Sistem Perdagangan Internasional. Jurnal Hukum Gloris Juris. Fakultas Hukum Universitas Katholik Atmajaya. Volume 7, Nomor 1. Jakarta: 1 Januari-April 2007. hal. 5.

${ }^{4}$ Christhophorus Barutu. Kententuan Antidumping, Subsidi, dan Tindakan Pengamanan (Safeguard) dalam GATT dan WTO. PT Citra Aditya Bakti. Bandung. 2007. hal. 2.

Uti Possidetis: Journal of International Law, Vol. 1, No. 2 (2020) 
perdagangan antar negara yang memiliki sistem perdagangan multilateral yang berisikan aturan-aturan dasar perdagangan. ${ }^{5}$

Tujuan dasar dari kegiatan perdagangan adalah untuk mendapatkan keuntungan yang sebesar-besarnya, dengan adanya globalisasi diharapkan dapat memberikan keuntungan sekaligus memenuhi kebutuhan nasional suatu negara demi terciptanya kerja sama ekonomi yang diwujudkan dalam bentuk penurunan, penyeragaman tariff atau penghapusan berbagai hambatan non-tariff. ${ }^{6}$ Kegiatan perdagangan yang semakin tidak ada batasan secara langsung meningkatkan hubungan kerja sama yang erat tanpa ada batas-batas tertentu (free trade) berdampak pada keterbukaan ekonomi yang dapat menjadi permasalahan baru. ${ }^{7}$

Permasalahan seperti ekspor dan impor terjadi karena setiap negara tidak dapat berdiri sendiri dan menyebabkan perdagangan bebas di negara-negara dunia semakin mudah dengan diperolehnya barang-barang yang tidak diproduksi oleh beberapa negara. ${ }^{8}$ Harga produk yang murah serta upah buruh yang rendah dapat menjadi alasan sebuah negara menjual barang dengan harga di bawah rata-rata, dan tidak menutup kemungkinan penawaran harga yang rendah dilakukan sebagai upaya monopoli pasar. Suatu negara mempunyai keunggulan dan kekurangan masing-masing contohnya pada teknologi, sumber daya manusia dan komoditas yang dihasilkan, hal ini disebabkan baik negara maju maupun negara berkembang memiliki karakteristik yang berbeda seperti sumber daya alam, kondisi geografis, iklim,

${ }^{5}$ Akbar Kurnia Putra. Agreement on Agriculture dalam World Trade Organization. Jurnal Hukum \& Pembangunan. Doi: http://dx.doi.org/10.21143/jhp.vol46.no1.37

${ }^{6}$ Wahono Diphayana. Op.cit. hal. 11.

${ }^{7}$ Wahono Diphayana. Op.cit. hal. 9.

${ }^{8}$ Ida BagusWyasa Putra. Aspek-Aspek Hukum Perdata Internasional dalam Transaksi Bisnis Internasional. Refika Aditama. Bandung. 2000. hal. 4 . 
demografi, struktur ekonomi dan sosial. Beberapa hal diatas menjadi salah satu faktor yang menyebabkan permintaan dan penawaran suatu komoditas dalam pasar global menjadi beragam, permintaan dan penawaran merupakan bentuk kesadaran akan pentingnya kegiatan perdagangan dan kerja sama untuk memenuhi kebutuhan yang berbeda di setiap negara. ${ }^{9}$

Berikut dampak positif dan dampak negatif dari kegiatan perdagangan internasional:

1. Dampak positif

a) Setiap negara dapat memperoleh barang yang tidak dapat diproduksi oleh negaranya sendiri.

b) Memperluas pasar bagi produk dalam negeri apabila produk tersebut mengalami tingkat produksi yang berlimpah sehingga dapat dijual ke negara lain demi meningkatkan devisa negara.

c) Menikmati hasil teknologi modern sebagai usaha melakukan investasi yang menguntungkan bagi negara berkembang.

2. Dampak negatif

a) Menghambat perkembangan industri dalam negeri, bagi konsumen yang berorientasi pada barang impor yang menyebabkan masyarakat dari negara pengimpor menjadi lebih konsumtif.

b) Menyebabkan ketergantungan kepada negara maju, dan bagi negara berkembang hal tersebut menyebabkan kondisi pasar menjadi tidak seimbang yang akhirnya berorientasi pada pemenuhan kebutuhan barang impor yang lebih terjamin.

${ }^{9}$ Gunawan Widjaya dan Ahmad Yani. SHB:Transaksi Bisnis Internasional. Raja Grafindo Persada. Jakarta. 2001. hal. 1. 
c) Negara maju akan mengendalikan kebutuhan dalam negeri. Akibatnya, usaha kecil menengah mengalami hambatan.

d) Tidak seimbangnya perkembangan teknologi antar negara menyebabkan persaingan yang tidak sehat.

Terlepas dari banyaknya kekurangan dan kelebihan perdagangan, nyatanya tidak selalu terbuka dan menimbulkan keuntungan bagi sebuah negara, salah satu dampak negatif tersebut berasal dari upaya-upaya yang dilakukan untuk melindungi pasar dalam negeri dari tindakan pencegahan persaingan yang cenderung bersifat politik ekonomi dan kepentingan pribadi. Ketergantungan terhadap negara maju ${ }^{10}$ menyebabkan negara berkembang mengalami kesulitan bersaing, negara maju memiliki peranan penting dalam kegiatan perdagangan serta pemegang kendali persaingan pasar. Kurangnya usaha bersaing produsen dapat menyebabkan produsen sangat bergantung pada subsidi yang diberikan oleh pemerintah, oleh karena itu kegiatan perdagangan yang dilakukan dapat memicu terjadinya persaingan yang tidak sehat (Unfair Trade Practices).

Persaingan memang diperlukan produsen antar negara yang dilandasi dengan tujuan untuk menguasai pasar dengan jangkauan yang luas, namun persaingan yang semakin ketat menyebabkan persaingan tersebut nyatanya tidak selalu adil dan biasanya menjadi sengketa antar negara, tidak jarang produsen suatu negara menurunkan harga tidak rasional (dumping) ${ }^{11}$ hingga tingkat terendah dari harga internal yang berlaku dalam suatu negara. Hal tersebut dilakukan dengan

10 Venita Sri Hadiarianti. Langkah Awal Memahami Hukum Perdagangan Internasional Dalam Era Globalisasi. Grafindo. Jakarta, cet 2. 2019. hal. 6 .

11 Ida Bagus Wyasa Putra. op. cit. hal. 12.

Uti Possidetis: Journal of International Law, Vol. 1, No. 3 (2020) 
tujuan untuk menguasai pasar dan demi mendapatkan keuntungan yang besar dengan merebut jangkauan pasar domestik yang berada dalam wilayah suatu negara. ketidakjujuran yang dilakukan produsen terhadap harga menyebabkan merosotnya produksi dan pemasaran produkproduk sejenis yang dapat merugikan negara tuan rumah. ${ }^{12}$

Penurunan harga yang tidak rasional secara langsung mendorong pemerintah melakukan berbagai cara untuk melindungi produsen dan pasar domestiknya dari perilaku curang kerja sama lintas batas antar negara. Berdasarkan latar belakang tersebut merupakan salah satu faktor yang menyebabkan negara-negara maju menetapkan kebijakan perlindungan dengan memberlakukan perangkat hukum bagi produsen dan pasar domestinya (Anti-Dumping), maupun melarang kehadiran produk asing ke dalam negara (protectionistic) atau dengan cara membebankan bea masuk tinggi kepada negara yang dianggap merugikan, hal tersebut dijadikan alasan sebagai upaya untuk menolak produk-produk dari negara berkembang.

Kegiatan pencegahan dumping seperti Anti-Dumping dan proteksionisme yang dilakukan negara maju nyatanya menjadi sumber kerugian dan kegiatan perdagangan yang tidak adil. ${ }^{13}$ kebijakan Anti-Dumping dan proteksionisme apabila disalahgunakan dapat memicu terjadinya persaingan yang tidak sehat (Unfair Trade Practices). Praktek perdagangan yang tidak adil tersebut secara langsung dapat memperhambat pertumbuhan sektor industri dan memperburuk kegiatan ekonomi pada negara berkembang.

Negara-negara berkembang pada dasarnya tidak dapat lagi bebas menawarkan barang domestiknya kepada negara maju sebagaimana mestinya. Kebijakan-kebijakan yang

12 Ida Bagus Wyasa Putra. loc. cit

13 Ibid. hal. 11.

Uti Possidetis: Journal of International Law, Vol. 1, No. 2 (2020) 
ditetapkan digunakan sebagai perisai oleh negara maju untuk melindungi pasar dengan cara memberikan tuduhan dumping ${ }^{14}$ atau secara tegas menolak produk dari negara berkembang sehingga menyebabkan Unfair Trade Practices.

\section{B. Metode Penelitian}

Dalam penulisan penelitian ini, metode yang digunakan adalah hukum normatif dengan menggunakan pendekatan Undang-Undang (Statute Approach). Penelitian hukum normatif biasanya disebut juga sebagai penelitian kepustakaan dengan data sekunder, peraturan Perundang-Undangan, teori hukum dan pendapat para sarjana yang terkait dengan isu hukum yang ditangani ${ }^{15}$ Dengan studi dokumen yang ditujukan selanjutnya akan digunakan untuk melakukan kajian dan penelitian dengan mencari jawaban pada peraturanperaturan yang tertulis saja atau dengan bahan-bahan hukum lain ${ }^{16}$ khususnya instrument internasional dalam GATT.

\section{Pembahasan Dan Analisis}

1. Dumping dan kebijakan Anti-Dumping dalam GATT/WTO

Masalah-masalah perdagangan yang terdapat dalam GATT diatur dalam rangkaian perundingan yang bersifat multilateral yang dikenal dengan Putaran Perdagangan (Trade Round). Pengertian Unfair Trade Practice adalah persaingan

14 FX. Joko Priyono. Beberapa Aspek Aplikasi Antidumping Agreement Pada Negara Sedang Berkembang. Jurnal Fakultas Hukum Universitas Diponegoro. Semarang. Vol. 39, No.1, 2010. hal. 2.

15 Peter Mahmud Marzuki . Penelitin Hukum. Kencana Pernada Media Group. Jakarta. hal. 93.

16 I Made Pesek Dianta. Metodologi Penelitian Hukum Normatif. Pernada Media Group. Jakarta. 2016. hal. 82.

Uti Possidetis: Journal of International Law, Vol. 1, No. 3 (2020) 
pelaku bisnis dalam menjalankan kegiatan produksi, pemasaran barang atau jasa yang dilakukan dengan tidak adil dan jujur bahkan melawan hukum untuk menghambat persaingan bisnis yang berdampak pada dunia perdagangan. Salah satu bentuk Unfair Trade Practice adalah masalah dumping. ${ }^{17}$

Dumping adalah kegiatan dagang yang dilakukan oleh negara pengekspor dengan menjual komoditas di pasar internasional dengan harga yang kurang dari nilai wajar atau lebih rendah dari harga barang tersebut di negaranya sendiri. Praktik dumping tersebut dinilai tidak adil karena dapat merusak pasar dan merugikan pesaing dinegara importir. ${ }^{18}$

Negara yang melakukan dumping biasanya memiliki beberapa alasan:

a) Pertama, dalam usaha untuk pengembangan pasar, yaitu dengan memberikan insentif melalui pemberlakuan harga yang lebih rendah kepada pembeli.

b) Kedua, adanya peluang untuk memungkinkan penentuan harga secara leluasa dalam pasar ekspor maupun domestik.

c) Ketiga, untuk mempersiapkan persaingan dan pertumbuhan ekonomi jangka panjang dengan memanfaatkan strategi penerapan harga.

Dalam keadaan tertentu, dumping boleh dilakukan dalam perdagangan internasional. Namun, dumping akan dilarang apabila penurunan harga terhadap suatu barang dilakukan melampaui batas kewajaran secara merugikan dan menentang hukum. ${ }^{19}$ Dampak dari kegiatan dumping yang

17 Ida Bagus Wyasa Putra. op. cit. hal. 11.

18 Muhammad Sood. Hukum Perdagangan Internasional. Raja Grafindo. Jakarta. 2011. hal. 115.

19 Ida Bagus Wyasa Putra. op. cit. hal. 13.

Uti Possidetis: Journal of International Law, Vol. 1, No. 2 (2020) 
paling mudah terlihat adalah menyempitnya jangkauan pasar produsen tuan rumah yang mengakibatkan turunnya pendapatan suatu negara serta menyebabkan penurunan daya bayar perusahaan sekaligus akan berdampak pada pemberian ongkos tenaga kerja yang secara langsung menurunkan tingkat daya hidup bagi perusahaan dalam hal ini kegiatan ekspor menjadi terhambat.

Kebijakan Anti-Dumping awalnya digunakan untuk mencegah praktek dumping yang dalam perdagangan internasional, ${ }^{20}$ hal ini dituangkan dalam GATT pada Article VI yang menyatakan:

order to offset or prevent dumping, a contracting party may levy on any dumped product.

an Anti-dumping duty not greater in amount than the margin of dumping in respect of such product.

Ketentuan ini menyatakan setiap negara yang terkena dumping wajib membebankan kebijakan Anti-Dumping yang seimbang. Dalam berbagai kesempatan, fenomena dumping dan pencegahannya telah diselidiki dengan cermat lebih dari satu abad yang lalu. Namun, sampai saat ini hal tersebut masih merupakan isu yang paling sulit dipahami dan diperdebatkan dalam kebijakan perdagangan karena digunakan untuk tujuan perlindungan dan melecehkan mitra dagang. ${ }^{21}$ Dalam memahami masalah dumping perlu menerapkan beberapa mekanisme yang efektif, yakni perbandingan tarif dan tugas dari anti-dumping tersebut ${ }^{22}$

20 Ibid. hal. 14.

21 Kerr, W.A. Dumping One of Those Economic Myths, The Estey Centre Journal of International Law and Trade Policy. 2010, hal. 211-220.

22 Kao, K.F. and Peng, C.H. Anti-Dumping Protection, Price undertaking and Product innovation. International Review\& Economics \& Finance. 2016. hal. 53-64.

Uti Possidetis: Journal of International Law, Vol. 1, No. 3 (2020) 
Dalam pasal VI mengatur tentang ketentuanketentuanAnti-Dumping yang dibentuk atas persetujuan dari anggota-anggota GATT dalam Tokyo Round, 1 Januari 1967. Dasar pembentukan ketentuan ini adalah untuk mengatur penerapan Anti-Dumpingyang lebih konstruktif. Ketentuan ini menyatakan: ${ }^{23}$

...Anti-Dumping duties may be applied against dumping only if such dumping causes are threatens material injury to established industry or materially retards the established of an industry;

It is desirable to provide for equitable and open procedures as the basic for a full examination of dumping cases;

To interpret the provisions of Article VI of the general Agreement and to elaborate rules for the application in order to provide greater uniformity and certainty in their implementation.

Hal ini berlaku dalam pasal-pasal yang termuat dalam GATT dan harus sesuai dengan prosedur yang telah ditetapkan dalam Anti-Dumping Code. Kriteria umum tentang dumping yang tidak diperbolehkan terdapat pada pasal VI ayat (1) GATT 1947, yaitu: ${ }^{24}$

a) Dumping dilakukan dengan bukti suatu negara menjual barang di bawah harga normal atau disebut juga dengan less than fair value.

b) Adanya bukti kerugian material yang disebabkan oleh barang impor terhadap barang sejenis di pasar domestik negara pengimpor.

c) Adanya hubungan causal link antara dumping dengan adanya kerugian.

23 GATT Document L/2812 (July 12, 1967).

24 Tubagus Satria Wibawa dan Made Maharta Yasa. Kebijakan AntiDumping World Trade Organization Sebagai Bentuk Tindakan Proteksi-Studi Kasus Bea Masuk Anti-Dumping Uni Eropa Kepada Impor Biodesel Indonesia. Kertha Negara: Jurnal Ilmu Hukum.Vol.7, No.6, 12 Juni 2019. hal. 6.

Uti Possidetis: Journal of International Law, Vol. 1, No. 2 (2020) 
Berdasarkan kriteria umum tersebut, tindakan Antidumping boleh dijatuhkan sebagaimana dalam pasal VI GATT ayat (1) menurut ketentuan ini bahwa setiap negara anggota GATT yang terbukti terkena dumping berhak melakukan tindakan antisipasi yang berupa pembebanan Anti-dumping yang seimbang seperti yang dinyatakan dalam Pasal VI 1994:

The contracting parties recognize that dumping, by which product of one country are introduced into the commerce of another country at less than the normal value of the products $^{25}$

Kewajiban tersebut adalah pembebanan bea khusus yang tidak boleh melampaui jumlah subsidi yang diberikan, atau dalam Anti-Dumping Duties harus setara dengan harga ekspor dengan nilai wajar yang berlaku pada negara pengekspor. Pembebanan bea khusus dapat dilakukan apabila terdapat suatu kondisi yang dinilai sebagai Threatens Material Injury terhadap negara pengimpor akibat adanya praktik dumping. ${ }^{26}$ termuat dalam pasal VI GATT:

...dumping...is to be condemned if it causes af threatens material injury to an established industry in the territory of a contracting party or materially retards the establishment of a domestic industry;

\section{Prosedur Anti-Dumping dalam kebijakan Anti- Dumping Code}

Dalam kebijakan Anti-Dumping Code, kewajiban AntiDumping hanya dapat dibebankan sesuai dengan ketentuanketentuan dalam GATT dan dengan adanya bukti bahwa negara yang bersangkutan bersalah melakukan dumping, yaitu mengenai ketentuan tersebut hanya dapat dilakukan dengan penjabaran dan proses yang sesuai. Ketentuan ini berisikan

25 GATT 1947.Article VI(ayat 1). Hal 9.

26 Ida Bagus Wyasa Putra. op. cit. hal. 15.

Uti Possidetis: Journal of International Law, Vol. 1, No. 3 (2020) 
mengenai pembuktian ada atau tidaknya kerugian material suatu negara (Material Retardation) dengan menggunakan prosedur dan administrasi (Investigation procedure and Administration Procedure)

Dalam Anti-Dumping Code pasal 1 memuat beberapa ketentuan mengenai pemberlakuan Anti-dumping:27

a.) Penentuan ada atau tidaknya Dumping (Determinations of dumping)

Sebuah produk dinilai termasuk dalam dumping apabila barang tersebut dijual dengan harga yang lebih rendah dari nilai normalnya di suatu negara tertentu, atau harga ekspor produk tersebut lebih rendah dari harga normal yang berada dalam pasaran yang berlaku untuk barang yang sejenis

b.) Penentuan kerugian

Dalam menentukan kerugian hanya dilakukan apabila terdapat pemasaran produk ekspor yang secara langsung menimbulkan kerugian atau ancaman kerugian terhadap perusahaan domestik pengimpor. Penentuan ini wajib didasarkan pada data yang pasti dan bukan terpaku pada data yang bersifat dugaan belaka.

c.) Penyelidikan

Penyelidikan terhadap dugaan dumping dasarnya dilakukan oleh negara yang merasa dirugikan, dengan data ada atau tidaknya dumping serta pengaruh terhadap industri Dalam negerinya.

d.) Bukti

Berdasarkan kepentingan dalam memperoleh bukti penyelidikan dapat dilakukan di negara ketiga atau di perusahaan lain atas persetujuan negara-negara terkait.

Namun apabila tuduhan dumping diberikan dengan alasan yang tidak tepat maka hal ini justru merugikan bagi negara pengeskpor terlebih pada tuduhan-tuduhan yang nyatanya

27 Ida Bagus Wyasa Putra. op. cit. hal. 19-20.

Uti Possidetis: Journal of International Law, Vol. 1, No. 2 (2020) 
tidak terbukti. Tuduhan yang diberikan negara maju nyatanya dapat berdampak langsung pada citra perdagangan sebuah negara.

\section{Penyalahgunaan Pasal VI GATT}

Dalam kegiatan perdagangan internasional tidak sedikit strategi dan politik ekonomi mengenai Anti-Dumping yang tidak sesuai dengan ketentuan dalam WTO. Salah satunya adalah penyalahgunaan pasal VI GATT. Pasal VI GATT sering disalahgunakan sebagai alat proteksi oleh produsen negara maju sebagai dasar untuk melakukan tuduhan dumping terhadap negara berkembang apabila tuduhan tersebut semata-mata hanya untuk memproteksi pasar domestiknya. Apabila negara penuduh selama pembuktian melakukan diskriminasi atau pemberhentian impor sementara atau tindakan serupa lainnya, dan apabila tuduhan tersebut nyatanya tidak terbukti maka penyimpangan tersebut merupakan penyimpangan terhadap pasal VI GATT yang dianggap sebagai Unfair Trade Practices, dan secara tidak langsung bentuk penyalahgunaan pasal ini merupakan bentuk lain dari proteksi. ${ }^{28}$

\section{Mengenal Proteksionisme dalam Perdagangan Internasional}

Proteksionisme (protectionism) adalah sebuah kebijakan yang boleh diambil oleh suatu negara untuk membatasi jumlah ekspor yang dilakukan negara lain yang bertujuan untuk melindungi kepentingan industri domestik dari ancaman kompetitor asing. Proteksionisme dalam pelaksanaannya mengandung dua makna yaitu:

a.) pertama, merupakan pemahaman yang menekankan pada usaha pemerintah untuk melindungi dunia usaha.

28 Ida Bagus Wyasa Putra. op.cit. hal. 16.

Uti Possidetis: Journal of International Law, Vol. 1, No. 3 (2020) 
b.) Kedua, merupakan usaha pemerintah untuk memberikan hambatan berupa tariff kuota, pajak dan lain-lain untuk melindungi industri dalam negeri terhadap ekspor atau impor negara lain sebagai instrumen untuk menekan impor dengan aturan fundamental yang melarang impor. ${ }^{29}$

Menurut Adam Smith proteksionisme muncul sebagai aksi akibat dari ketidakpuasan akan pasar bebas yang dirasa tidak sesuai dengan kepentingan nasional suatu negara. Proteksionisme dipakai oleh negara maju didasari karena adanya perdagangan bebas, pada hakikatnya kebijakan ini hanya menguntungkan bagi negara maju saja sebab negara maju memiliki teknologi dan modal yang maju pula, akan tetapi disisi lain harga jual suatu produk di negara maju dinilai lebih tinggi dibanding negara berkembang sehingga negara maju berupaya untuk melindungi industri dalam negerinya agar tetap hidup dan sekaligus mampu membuka lapangan pekerjaan bagi masyarakatnya. ${ }^{30}$

\section{Kebijakan Anti-Dumping dalam Prinsip GATT/WTO}

Hal lain yang juga mendasari adalah dalam prinsip dasar GATT/WTO yakni Prinsip Perlakuan yang sama untuk semua anggota (Most Favoured Nation Treatment). ${ }^{31}$ Prinsip ini menekankan pada kebijakan perdagangan internasional yang harus dilakukan atas dasar non-diskriminasi. Artinya, setiap negara yang tergabung dalam anggota harus memberikan perlakuan yang sama dalam kebijakan ekspor dan impor, dan dilakukan tanpa syarat terhadap produk-produk yang ditujukan ke semua negara anggota dan tidak boleh memberikan perlakuan yang istimewa atau melakukan

29 Laode Muhamad Fathun. "Asia Pacific Studies: Journal of International Relations Study Program Faculty of Social and Political Science", vol 1 no 1. Januari-juni 2017. hal. 19. Ibid.

31 Christhophorus Barutu. op. cit. hal. 24.

Uti Possidetis: Journal of International Law, Vol. 1, No. 2 (2020) 
tindakan diskriminasi lainnya. ${ }^{32}$ contohnya, suatu negara tidak diperbolehkan untuk melakukan penerapan tariff yang berbeda dibandingkan dengan negara lainnya dalam keanggotaan GATT.

Prinsip MFN adalah prinsip utama yang mengatur tentang perdagangan barang. ${ }^{33}$ Namun nyatanya prinsip ini membawa kerugian bagi negara tertentu dikarenakan dalam menghadapi barang-barang dumping, importir diperkenankan untuk menyimpang dari prinsip ini, artinya negara importir berhak mengambil tindakan tertentu untuk melindungi industri domestiknya dari dampak dumping yang merugikan. dengan menetapkan tariff yang diskriminatif terhadap barang impor yang terbukti dijual dengan harga dumping ataupun barang impor yang menyebabkan ruginya industri dalam suatu negara. ${ }^{34}$ Dengan pengecualian tersebut perlakuan diskriminasi harga yang diberikan oleh negara maju terhadap beberapa negara berkembang berujung pada kerugian, pada prinsip ini semua negara yang tergabung dalam keanggotaan GATT wajib mempertimbangkan segala bentuk penerapan kebijakan demi mengurangi kegiatan perdagangan yang tidak adil. Prinsip yang disepakati dalam Putaran Uruguay (19861994) negara maju tidak seharusnya mengharapkan tindakan imbalan (nonresiprositas) dari negara berkembang, dikarenakan negara berkembang perlu mendapatkan perhatian khusus terhadap berbagai masalah yang sedang dihadapi.

Prinsip lainnya yang perlu dikaji adalah prinsip Standstill and Rollback, prinsip ini diatur dalam pasal XXXVIII tentang Commitments dimana prinsip ini menekankan bahwa negara maju tidak diperkenankan untuk menciptakan hambatan-

32 Astim Riyanto. World Trade Organization (Organisasi Perdagangan Dunia). Yapemdo. Bandung. 2003. hal. 54.

33 Christhophorus Barutu. loc. cit

34 FX. Joko Priyono. loc. cit

Uti Possidetis: Journal of International Law, Vol. 1, No. 3 (2020) 
hambatan yang berupa proteksi, pasal tersebut juga memberikan prioritas utama untuk melaksanakan reduksi dan penghapusan hambatan-hambatan produk, khususnya yang berasal dari negara berkembang. prinsip ini ditujukan kepada negara maju dengan tujuan agar menjaga segala tindakannya yang secara langsung dapat menghalangi produk-produk primer sebagai bahan baku atau bahan yang sedang diproses yang sebagian atau seluruhnya berasal dari negara berkembang. ${ }^{35}$

Negara berkembang sebenarnya telah diberikan kesempatan oleh negara maju untuk meningkatkan keikutsertaanya dalam kegiatan perdagangan. Dalam prinsip dasar GATT negara berkembang secara spesifik diatur dalam Prinsip Perlakuan Khusus dan Berbeda bagi Negara Berkembang (Special and Differential Treatment for Developing Countries - $S \& D$ ) yang diatur sebagai wujud untuk mendorong nagara berkembang aktif dalam berbagai kegiatan perdagangan internasional termasuk memberikan kemudahan-kemudahan bagi negara berkembang untuk melaksanakan kebijakan WTO. ${ }^{36}$

Adapun beberapa pengecualian terhadap prinsip diatas mengenai ketentuan kegiatan perdagangan yang dilakukan oleh negara berkembang:

a) Kerja Sama Regional, Bilateral dan Custom Union Pada Article XXIV GATT 1994 anggota WTO diperkenankan untuk membentuk kerja sama perdagangan yang bersifat regional, bilateral dan custom union dengan syarat mengikuti aturan yang berlaku dan tidak merugikan anggota WTO Lainnya.

b) Pengecualian Umum

Berdasarkan Article XX GATT 1994 menegaskan suatu negara diperbolehkan untuk melakukan

35 Christhophorus Barutu. op.cit. hal. 12.

36 Christhophorus Barutu. op.cit. hal. 28.

Uti Possidetis: Journal of International Law, Vol. 1, No. 2 (2020) 
hambatan perdagangan apabila dengan alasan untuk melindungi kesehatan manusia, tumbuhtumbuhan, hewan dan barang impor yang bertentangan dengan moral, konservasi hutan, perdagangan barang-barang pustaka atau bernilai budaya dan perdagangan emas murni.

c) Tindakan Anti-Dumping dan Subsidi.

Pada Article VI GATT pengenaan bea masuk AntiDumping dan bea imbalan hanya boleh dijatuhkan kepada perusahaan yang terbukti melanggar, yakni melakukan dumping dan mendapatkan subsidi.

d) Tindakan Safeguard

Safeguard memperkenankan suatu negara untuk mengenakan kuota terhadap suatu produk impor yang mengalami lonjakan yang merugikan industri.

e) Tindakan Safeguard untuk mengamankan Balance of Payment.

f) Sanitary and Phytosanitary

g) Melarang suatu produk yang terbukti mengandung penyakit menular atau penyakit berbahaya yang dapat membahayakan kesehatan manusia, hewan dan tumbuh-tumbuhan. ${ }^{37}$

Berdasarkan pengecualian diatas, jelas terlihat bahwa negara berkembang diberikan peluang oleh negara maju untuk ikut serta dalam kegiatan perdagangan dengan mengurangi hambatan-hambatan tertentu, hal tersebut dilakukan dengan memberikan perlakuan yang khusus bagi negara berkembang untuk membuka pangsa pasar yang lebih terbuka guna meningkatkan perekonomian dengan syarat pengecualian yang telah ditetapkan. Berdasarkan prinsip-prinsip tersebut dalam kaitannya dengan memberikan kebijakan Anti-Dumping dan tindakan proteksi proteksi bagi negara berkembang nyatanya tidak sejalan dengan ketentuan yang disepakati dengan kenyataan yang terjadi dalam perdagangan itu sendiri.

37 Ibid.

Uti Possidetis: Journal of International Law, Vol. 1, No. 3 (2020) 
Prinsip tersebut diciptakan untuk mendukung kegiatan perdagangan yang harmonis, adil dan terbuka.

Namun praktiknya politik ekonomi muncul sebagai dampak persaingan yang tidak selalu terbuka, perlunya suatu pengaturan yang digunakan untuk memisahkan antara penyimpangan-penyimpangan yang terjadi, sebagai implikasi dari hubungan perdagangan internasional harus dilakukan dengan menetapkan ketentuan sebagai instrumen pengamanan guna melindungi seluruh negara anggota dari kegiatan perdagangan curang yang dilakukan mitra bisnisnya. ${ }^{38}$

Disisi lain, hal ini menciptakan persoalan baru, berdasarkan tujuan yang ingin dicapai dalam GATT, yakni menciptakan perdagangan bebas (Free Trade) tanpa hambatan nyatanya masih jauh dari harapan terutama kebijakan pengurangan atau penghapusan tariff dan non-tariff dengan anggapan bahwa pasar dalam negeri semakin terbuka terhadap barang-barang impor yang pada akhirnya tidak terkendali akan menghancurkan produk dalam negeri akibat tidak mampu bersaing dengan barang impor. Situasi tersebutlah yang menciptakan Unfair Trade Practices yang dapat menghancurkan perekonomian suatu negara dan bertentangan dengan prinsip dasar GATT/WTO.

Bagi negara berkembang bersaing dengan negara maju memang merupakan hal yang sulit, negara maju memiliki peranan penting dalam dunia perdagangan internasional dan juga sebagai pengendali pasar. Bila dilihat secara terbuka negara berkembang sebenarnya belum siap untuk menjalankan perdagangan bebas hal tersebut dapat menjadi alasan dalam permasalahan yang dihadapi, dari berbagai

38 Tempo. https://www.google.com/amp/s/bisnis.tempo.co/11413 34/kemendag-ingin-kebijakan-anti-dumping-anti-subsidi-

semakin-digencarkan diakses pada tanggal 15 september pukul 12:30

Uti Possidetis: Journal of International Law, Vol. 1, No. 2 (2020) 
tuduhan dumping memang ada negara yang bertujuan untuk melakukan proteksionisme melalui politik dumping, namun hal tersebut dianggap biasa karena penerapan pasal VI GATT selalu dijadikan alasan untuk melindungi komoditas dalam negerinya sehingga hal ini sering terjadi dalam kegiatan perdagangan internasional.

Perlu dipahami bahwa banyak sekali faktor lainnya yang mempengaruhi suatu komoditi yang dijual dengan harga murah. yaitu:

a.) setiap negara memiliki keunggulan terhadap beberapa komoditas tertentu sehingga karena kelebihan tersebut tak jarang negara-negara yang mengalami kelebihan komoditas unggulan menjual barang tersebut dengan harga yang lebih murah ke negara lain.

b.) Perbedaan nilai tukar mata uang, hal ini menjadi salah satu faktor yang menyebabkan harga suatu komoditas negara berkembang dijual dengan harga yang lebih murah, karena nilai tukar mata uang negara berkembang jelas lebih kecil dibanding negara maju.

Apabila tuduhan dumping dibiarkan akan sangat berdampak pada ekspor di negara berkembang yang secara langsung dapat menurunkan daya minta beli dari negara lain yang sebagaimana juga berlaku pada sumber saya manusia yang mengelola serta menjual komoditas yang terkena praktek Anti-Dumping. Para produsen akan mengalami kerugian yang besar dan beberapa usaha kecil menengah yang baru saja tumbuh tidak dapat lagi berkembang, dampak selanjutnya adalah kerugian bagi negara pengekspor yang akan mempengaruhi ekonomi negara tersebut.

Dengan sistem Anti-Dumping Act yang bersifat nasional dan berbeda disetiap negara, penjatuhan dan tuduhan dumping menjadi lebih leluasa dijatuhkan dan sangat 
subjektif. Perselisihan yang terjadi dapat berkembang lebih banyak karena pada dasarnya setiap negara menggunakan ukuran atau standar dalam menentukan praktik dumping akan berbeda. Jika hal ini terjadi, maka Anti-dumping juga dapat menjadi alat proteksi dan perdagangan akan masuk dalam kondisi persaingan yang tidak sehat. ${ }^{39}$

\section{Penutup}

Berdasarkan pembahasan permasalahan di atas dapat disimpulkan bahwa kegiatan perdagangan internasional diharapkan dapat berjalan bebas dan adil. Ketentuan AntiDumping dan proteksionisme jelas berbeda pengertiannya, melalui beberapa ketetapan dan penjelasan dapat disimpulkan bahwa importir harus memahami dan mengetahui kapan nagara eksportir dikatakan melakukan dumping dengan menerapkan kebijakan pencegahan agar memunculkan efek positif sebagai mitra dagang dan bukan dengan melayangkan tuduhan yang bersifat menjatuhkan. pentingnya kesepakatan, informasi serta negosiasi diupayakan agar meminimalisir kerugian yang tidak sesuai dengan semboyan perdagangan bebas yang berlaku bagi setiap negara.

Negara maju sebagai aktor penting memiliki peran besar dalam mengurangi hambatan demi terwujudnya kesejahteraan perdagangan diseluruh dunia dengan mempertimbangkan bahwa negara berkembang juga memiliki hak dan posisi yang sama sebagai mitra dagang. Penelaah lebih jauh dan koordinasi antara ketentuan yang berlaku internasional dengan beberapa kebijakan nasional tiap negara memungkinkan praktek semacam ini dapat dihindari dan dikurangi. WTO sebagai organisasi dunia juga memiliki tugas dalam mengawasi setiap tindakan baik kerja sama, politik

${ }^{39}$ Ida BagusWyasa Putra.op.cit. hal. 17.

Uti Possidetis: Journal of International Law, Vol. 1, No. 2 (2020) 
balas budi, politik ekonomi serta berbagai hal yang memperhambat kegiatan dagang demi terciptanya perdagangan yang terbuka dan adil.

\section{Referensi}

\section{Instrumen Hukum}

General Agreement on tarrifs and Trade (GATT) tahun 1994

\section{Buku}

Barutu, Christhophorus. Kententuan Anti dumping, Subsidi, dan

Tindakan Pengamanan (Safeguard) dalam GATT dan WTO. PT Citra Aditya Bakti. Bandung. 2007.

Dianta ,I Made Pesek. Metodologi Penelitian Hukum Normatif. Pernada Media Group. Jakarta. 2016.

Diphayana, Wahono. Perdagangan internasional. Deeppublish. Ngaglik. Sleman. 2018.

Hadiarianti, Venita Sri. Langkah Awal Memahami Hukum

Perdagangan Internasional Dalam Era Globalisasi. Grafindo. Jakarta. cet 2. 2019.

Marzuki, peter Mahmud. Penelitian Hukum. Kencana Prenada Media Group. Jakarta. 2005.

Putra, Ida Bagus Wyasa. Aspek-Aspek Hukum Perdata Internasional dalam Transaksi Bisnis Internasional. Refika Aditama. Bandung. 2000.

Riyanto, Astim. World Trade Organization (Organisasi Perdagangan Dunia). Yapemdo. Bandung. 2003.

Sood ,Muhammad. Hukum Perdagangan Internasional. Raja Grafindo. Jakarta. 2011.

Widjaya ,Gunawan dan Ahmad Yani. SHB: Transaksi Bisnis Internasional. Raja Grafindo Persada. Jakarta. 2001. 


\section{Artikel/Jurnal}

Athun, Laode Muhamad. Asia Pacific Studies: Journal of International Relations Study Program Faculty of Social and Political Science. Vol.1, No 1. Januari-Juni 2017.

Barutu, Christhophorus. Sejarah Sistem Perdagangan Internasional. Jurnal Hukum Gloris Juris. Fakultas Hukum Universitas Katholik Atmajaya, Vol.7, No.2, Jakarta: 1 Januari-April 2007.

Kao, K.F. and Peng, C.H., Anti-Dumping Protection, Price undertaking and Product Innovation, International Review \& Economics \& Finance. 2016. hlm. 53-64.

Kerr, W.A., Dumping One Of Those Economic Myths. The Estey Centre Journal of International Law and Trade Policy. 2010.hlm. 211-220.

Priyono, FX. Joko. Beberapa Aspek Aplikasi Anti dumping Agreement Pada Negara Sedang Berkembang. Jurnal Masalah-Masalah Hukum. Vol.39, No.1, 2010.

Putra, Akbar Kurnia. Agreement on Agriculture dalam World Trade Organization. Jurnal Hukum \& Pembangunan. Doi: http://dx.doi.org/10.21143/jhp.vol46.no1.37

Wibawa, Tubagus Satria, dan Yasa, Made Maharta. Kebijakan AntI-Dumping World Trade Organization Sebagai Bentuk Tindakan Proteksi-Studi Kasus Bea Masuk AntiDumping Uni Eropa Kepada Impor Biodesel Indonesia. Kertha Negara: Jurnal Ilmu Hukum. Vol.7, No.6, 12 Juni 2019.

\section{Laman}

https://www.google.com/amp/s/bisnis.tempo.co/1141334/k emendag-ingin-kebijakan-anti-dumping-anti-subsidisemakin-digencarkan 